\title{
Evaluation of EGFR, KRAS and BRAF gene mutations in renal cell carcinoma
}

\author{
Omer Bayrak ${ }^{1}$, Haluk Sen ${ }^{1}$, Ersan Bulut ${ }^{1}$, Beyhan Cengiz ${ }^{2,3}$, Metin \\ Karakok $^{4}$, Sakip Erturhan ${ }^{1}$, Ilker Seckiner ${ }^{1}$ \\ ${ }^{1}$ Department of Urology, ${ }^{3}$ Department of Physiology, ${ }^{4}$ Department of Pathology, University of Gaziantep, \\ Gaziantep, Turkey; 2Department of Medical Genetics, University of Gazi, Ankara, Turkey
}

\begin{abstract}
A subset of renal cell carcinoma (RCC) patients has been shown to respond to anti-EGFR therapy. As KRAS and BRAF mutations are associated with poor response to anti-EGFR therapy in some cancers, it has been suggested that screening for KRAS and BRAF mutations in RCC may be a promising strategy to identify patients who might respond to EGFR-targeted therapy. The aim of this study was to investigate the mutation status of EGFR, KRAS and BRAF in RCC patients. Renal tumors and normal renal samples from forty-eight patients who underwent radical or partial nephrectomy for kidney cancer were used in this study. Histological classification of the tumors was performed according to International Union against Cancer (UICC) / American Joint Committee on Cancer (AJCC) classification. Seventeen patients $(48 \%)$ had clear-cell RCC, $7(20 \%)$ had chromophobe RCC, and 11 patients (32\%) had papillary RCC. DNA isolated from the samples was subjected to melting curve mutation analysis for EGFR, BRAF and KRAS using ABI-3130 DNA sequencer. DNA sequencing analysis of RCC samples, when compared with morphologically normal matched regions, did not show any exon mutations. Our results do not support the notion that EGFR, KRAS and BRAF might be mutated in RCC. Copyright: The Authors.
\end{abstract}

Received: 06 June 2014; Accepted after revision: 31 July 2014; Published: 05 August 2014

Author for correspondence: Assistant Professor Omer Bayrak, University of Gaziantep, School of Medicine, Department of Urology, 27310, Gaziantep, Turkey. E-mail: Dromerbayrak@yahoo.com

How to cite: Bayrak O, Sen H, Bulut E, Cengiz B, Karakok M, Erturhan S, Seckiner I. Evaluation of EGFR, KRAS and BRAF gene mutations in renal cell carcinoma. Journal of Kidney Cancer and VHL 2014; 1(4):40-45.

Doi: http://dx.doi.org/10.15586/jkcvhl.2014.10

\section{INTRODUCTION}

Renal cell carcinoma (RCC) constitutes 3\% of all adult malignancies (1). According to Surveillance, Epidemiology, and End Results (SEER) data, the annual increase in RCC incidence is $2.5-3 \%$, as we have started to use modern imaging methods more frequently since 1970s (2). Although $60 \%$ of new diagnoses are coincidental, $25 \%$ of the patients are metastatic during the diagnosis (3). Radical nephrectomy or nephron sparing surgery is the standard treatment for localized RCC, while $30 \%$ of the patients experience recurrence after the surgery (3). Despite the tremendous improvements in our understanding of the molecular mechanisms of RCC, and the introduction of many novel multi-tyrosine kinase inhibitors in clinical practice for the treatment of RCC the five-year survival of metastatic patients continues to be less than $10 \%$. There is a need for a better understanding of the molecular mechanisms of RCC and the discovery of more efficient therapeutics for the management of metastatic RCC. The epidermal growth factor receptor (EGFR), a transmembrane tyrosine kinase receptor of the Erb family, is overexpressed in both 
primary and metastatic RCC (4-6) suggesting the potential of anti-EGFR agents as therapeutics for the treatment of RCC. While anti-EGFR therapy demonstrated effective anti-tumoric activity in laboratory settings $(7,8)$, clinical trials demonstrated a very low objective response (9). Of the 88 patients treated with ABXEGF, one complete, two partial, and two minor responses were observed (9). While the reasons for these disappointing results are not clear, it is possible that mutations of KRAS and BRAF are involved. This notion stems from the fact that, in colorectal cancer, mutations of KRAS/BRAF genes, which are integral part of the EGFR signaling pathway make EGFR inhibitors ineffective $(10,11)$. On the contrary, a case report demonstrates that EGFR mutations could sensitize patients to anti-EGFR therapy (12). Therefore, screening for EGFR, KRAS and BRAF mutations in RCC may be a promising strategy to identify patients who might respond to EGFR-targeted therapy. The present study aims to identify EGFR, KRAS and BRAF mutations in RCC.

\section{MATERIALS AND METHODS}

\section{Patient Selection}

After obtaining local ethics committee approval, RCC and matched normal samples from 48 patients who underwent radical or partial nephrectomy for kidney cancer were evaluated between June 2009 and June 2011 at the University of Gaziantep, Department of Urology, Turkey. Thirteen patients who had benign and ureteral carcinoma according to the pathological results were excluded from the study. The samples from the remaining 35 patients were used for further study. Portion of the samples were formalin-fixed and processed for histology and the remaining were stored at $-80^{\circ} \mathrm{C}$ until use.

\section{Histology}

Three micron sections of the formalin-fixed kidney samples were stained with hematoxyline and eosine and the tumor grade was determined according to International Union against Cancer (UICC) / American Joint Committee on Cancer (AJCC) 2009 TNM classification, whereas tumor nuclear grading was performed according to the Fuhrman grading system by a qualified Pathologist.

\section{Mutation Detection}

DNA from kidney samples that had been stored at $-80^{\circ} \mathrm{C}(30-50 \mathrm{mg}$ tissue) were isolated using Roche High Pure Polymerase Chain Reaction (PCR) Template Preparation Kit (Catalogue Number: 11796828 001) following the protocol of the supplier. DNA samples were stored at $-20^{\circ} \mathrm{C}$ until further use. DNA sequencing was performed on an ABI 3130 DNA sequencing analysis instrument. The target area was amplified by PCR using primers specific to EGFR, KRAS, and BRAF (Table 1).

The primers were designed specifically for the most mutation presenting regions of EGFR, BRAF and KRAS genes. These regions contained exons 18, 19, 21 for EGFR, exons 11, 15 for BRAF and exons 1, 2 for KRAS genes (13-15). The PCR conditions were the same for all PCR reactions. PCR products were visualized with agarose gel electrophoresis. After detecting the optimal size of PCR product, DNA sequencing was performed using BigDye ${ }^{\circledR}$ Terminator v1.1 Cycle Sequencing Kit (Applied Biosystem, SKU\#4337450).

The PCR mixture was kept at $96^{\circ} \mathrm{C}$ for 1 minute. Then, PCR was carried out with 25 cycles consisting of following steps: 10 seconds at $96^{\circ} \mathrm{C}, 5$ seconds at $50^{\circ} \mathrm{C}$, and 4 minutes at $60^{\circ} \mathrm{C}$. Samples were kept at $4^{\circ} \mathrm{C}$ until they were placed in the instrument. In automated DNA sequencing, PCR products were loaded into the instrument after a clean-up step through Sephadex. To do this, $1 \mathrm{~g}$ of Sephadex was dissolved in 14 $\mathrm{ml}$ of ultrapure water, and $600 \mu \mathrm{l}$ of this solution was transferred to the columns. After centrifugation at 2000xg for 2 minutes, Sephadex-containing columns were transferred to other tubes, and $10 \mu 1$ of PCR product was added on Sephadex. Centrifugation was performed at 2000xg for 2 minutes. Following centrifugation, the products at the bottom of the tube were subjected to DNA sequencing by Sanger dye-terminator sequencing method. Each dideoxynucleotide in the DNA sequence analysis was labelled with a different fluorescence dye. Amplified DNA fragments 
Table 1. PCR primers and product lengths of EGFR, BARF and KRAS

\begin{tabular}{|c|c|c|c|c|}
\hline Gene & Exon & & Primer sequences & $\begin{array}{c}\text { Product } \\
\text { length (bp) }\end{array}$ \\
\hline \multirow{6}{*}{ EGFR } & \multirow{2}{*}{18} & Forward & GTGAGGGCTGAGGTGACC & \multirow{2}{*}{186} \\
\hline & & Reverse & TGTGCCAGGGACCTTACC & \\
\hline & \multirow{2}{*}{19} & Forward & TGCCAGTTAACGTCTTCC & \multirow{2}{*}{155} \\
\hline & & Reverse & CACAGCAAAGCAGAAACTC & \\
\hline & \multirow{2}{*}{21} & Forward & TCTTCCCATGATGATCTGTC & \multirow{2}{*}{225} \\
\hline & & Reverse & GACCTAAAGCCACCTCCT & \\
\hline \multirow{4}{*}{ BRAF } & \multirow{2}{*}{11} & Forward & TGTTTGGCTTGACTTGAC & \multirow{2}{*}{176} \\
\hline & & Reverse & CACCACATTACATACTTACC & \\
\hline & \multirow{2}{*}{15} & Forward & TACTGTTTTCCTTTACTTAC & \multirow{2}{*}{165} \\
\hline & & Reverse & TAGCCTCAATTCTTACCA & \\
\hline \multirow{4}{*}{ KRAS } & \multirow{2}{*}{1} & Forward & GGCCTGCTGAAAATGACTGA & \multirow{2}{*}{162} \\
\hline & & Reverse & GTCCTGCACCAGTAATATGC & \\
\hline & \multirow{2}{*}{2} & Forward & CTGTAATAATCCAGACTGTG & \multirow{2}{*}{151} \\
\hline & & Reverse & TCCCCAGTCCTCATGTACTG & \\
\hline
\end{tabular}

were migrated through a "gel matrix", which were loaded in capillaries, and detected by an instrument capable of recognizing fluorescent dyes.

\section{RESULTS}

Nineteen male and 16 female patients (35 patients in total) who had RCC were included in the study. The mean age of the patients was calculated as $59.31 \pm 12.52$ (15-77) years. None of the patients were in an occupational group that might play a role in kidney cancer etiology. History of smoking was present in ten male patients $(52.6 \%)$ and in four female patients $(25 \%)$. The mean body mass index was $28.31 \pm$ $3.45(21-33) \mathrm{kg} / \mathrm{m}^{2}$. According to histopathological UICC and AJCC classification systems, 17 patients (48\%) had clear-cell RCC, 7 patients $(20 \%)$ had chromophobe cell RCC, and 11 patients (32\%) had papillary RCC. According to 2009 TNM staging of the tumors, 11 patients $(31 \%)$ were T1a, 8 patients $(23 \%)$ were T1b, 3 patients $(8 \%)$ were T2, 9 patients $(26 \%) \mathrm{T} 3 \mathrm{a}$, and 4 patients $(12 \%)$ T3b. Twenty-three patients $(65 \%)$ were evaluated as N0, 8 were $(23 \%) \mathrm{N} 1$, and 4 patients were $(12 \%) \mathrm{N} 2$. According to the Fuhrman grading system, 3 patients $(8 \%)$ were Grade 1, 15 patients (43\%) were Grade 2, and 17 patients were (49\%) Grade 3 (Table 2). DNA sequencing analysis of cancer samples and normal tissues did not show any exon mutations in the EGFR, BRAS, and KRAS pathway (data not shown).

\section{DISCUSSION}

BRAF and KRAS belong to the RAF protooncogene serine / threonine-protein kinase (c-RAF) gene family and their over expression or mutations trigger abnormal cell proliferation. EGFR is believed to be responsible for cell proliferation during carcinogenesis (16). Kamai et al. (17) evaluated the association of parathyroid hormone-related protein (PTHrP) and KRAS in RCC. Of the 51 patients, serum PTHrP and mRNA expression of KRAS were 
Table 2. Characteristics of patient samples

\begin{tabular}{|lcc|}
\hline \multicolumn{1}{|c}{ RCC subtype } & $\%$ & Number of samples \\
\hline Clearcell RCC & $48 \%$ & $(17 / 35)$ \\
Papillary RCC & $32 \%$ & $(11 / 35)$ \\
Chromophobe RCC & $20 \%$ & $(7 / 35)$ \\
\hline TNM & & \\
T1a & & \\
T1b & $31 \%$ & $(11 / 35)$ \\
T2 & $23 \%$ & $(8 / 35)$ \\
T3a & $8 \%$ & $(3 / 35)$ \\
T3b & $26 \%$ & $(9 / 35)$ \\
N0 & $12 \%$ & $(4 / 35)$ \\
N1 & $65 \%$ & $(23 / 35)$ \\
N2 & $23 \%$ & $(8 / 35)$ \\
& $12 \%$ & $(4 / 35)$ \\
Fuhrman's Classification & \\
Grade 1 & & $(3 / 35)$ \\
Grade 2 & $8 \%$ & $(15 / 35)$ \\
Grade 3 & $43 \%$ & \\
& $49 \%$ & \\
\hline
\end{tabular}

significantly high in 7 patients (17). Also, there was a correlation between high KRAS expression and PTHrP-induced hypercalcemia. However, the mutation status of KRAS was not studied. Kozma et al. (18) analyzed $36 \mathrm{RCC}$ samples for c-myc and KRAS amplification. Three samples $(8.3 \%)$ showed c-myc, and 6 samples $(16.6 \%)$ displayed KRAS amplifications. The authors also reported that the amplifications correlated with tumor grade and size but not with lymph node involvement. In a comprehensive analysis of 121 RCC samples, KRAS and BRAF did not reveal any mutations (19). In a multicenter study, Szymanska et al. (20) investigated the correlation between TP53 (exons 5-9), EGFR (exons 18-21) and KRAS (codon 12) mutation and Von HippelLindau (VHL) gene in tissue samples derived from 361 RCC $(334$ clear-cell carcinomas) patients. The authors observed TP53 mutation in 4\% of clear-cell carcinoma subtypes, which was independent of VHL mutations. EGFR and
KRAS mutations were not detected in any patients. The authors concluded that TP53, KRAS, or EGFR mutations do not have a major contribution to RCC development, provided that the VHL gene is not inactivated (20). Furthermore, Sakaeda and colleagues reported no mutations of EGFR in a cohort of Japanese patients (21). We studied EGFR, BRAF and KRAS mutation in a Turkish cohort, and did not find any mutations, corroborating previous findings. Screening for EGFR, KRAS and BRAF mutations in RCC is unlikely to be a promising strategy to identify patients who might respond to EGFR-targeted therapy.

\section{Acknowledgement}

This study was supported by the University of Gaziantep, Turkey.

\section{Conflict of interest}

No conflict of interest was declared by the authors. 


\section{References}

1. Jemal A, Sigel R, Ward E, Murray T, Xu J, Thun MJ. Cancer Statistics 2007. CA Cancer J Clin 2007; 57: 43-66.

DOI:

http://dx.doi.org/10.3322/canjclin.57.1.43

2. Hock LM, Lynch J, Balaji KC. Increasing incidence of all stages of kidney cancer in the last 2 decades in the United States: An analysis of surveillance, epidemiology and end results program data. J Urol 2002; 167: 57-60.

DOI:

http://dx.doi.org/10.1016/S0022$\underline{\text { 5347(05)65382-7 }}$

3. Janzen NK, Kim HL, Figlin RA, Belldegrun AS. Surveillance after radical or partial nephrectomy for localized renal cell carcinoma and management of recurrent disease. Urol Clin North Am 2003; 30: 843-852.

DOI:

http://dx.doi.org/10.1016/S0094$\underline{0143(03) 00056-9}$

4. Pu YS1, Huang CY, Kuo YZ, Kang WY, Liu GY, Huang AM, Yu HJ, Lai MK, Huang SP, Wu WJ, Chiou SJ, Hour TC. Characterization of membranous and cytoplasmic EGFR expression in human normal renal cortex and renal cell carcinoma. J Biomed Sci. 2009;16:82.

DOI:

http://dx.doi.org/10.1186/1423-0127-16-82

5. Dorđević G, Matušan Ilijaš $K$, Hadžisejdić $I$, Maričić A, Grahovac B, Jonjić N. EGFR protein overexpression correlates with chromosome 7 polysomy and poor prognostic parameters in clear cell renal cell carcinoma. J Biomed Sci. 2012; 5:19:40.

DOI:

http://dx.doi.org/10.1186/1423-0127-19-40.

6. Langner C, Ratschek M, Rehak P, Schips L, Zigeuner R.Are heterogenous results of EGFR immunoreactivity in renal cell carcinoma related to non-standardised criteria for staining evaluation? J Clin Pathol. 2004; 57:773-5.

DOI:

http://dx.doi.org/10.1136/jcp.2003.015743

7. Prewett M1, Rothman M, Waksal H, Feldman $\mathrm{M}$, Bander NH, Hicklin DJ. Mouse-human chimeric anti-epidermal growth factor receptor antibody $\mathrm{C} 225$ inhibits the growth of human renal cell carcinoma xenografts in nude mice. Clin Cancer Res. 1998; 4:2957-66. [Pubmed]

8. Weber KL1, Doucet M, Price JE, Baker C, Kim SJ, Fidler IJ. Blockade of epidermal growth factor receptor signaling leads to inhibition of renal cell carcinoma growth in the bone of nude mice. Cancer Res. 2003; 63:2940-7. [Pubmed]

9. Rowinsky EK, Schwartz GH, Gollob JA, Thompson JA, Vogelzang NJ, Figlin R, Bukowski R, Haas N, Lockbaum P, Li YP, Arends R, Foon KA, Schwab G, Dutcher J. Safety, pharmacokinetics, and activity of ABX-EGF, a fully human anti-epidermal growth factor receptor monoclonal antibody in patients with metastatic renal cell cancer. J Clin Oncol. 2004; 22:3003-15.

DOI:

http://dx.doi.org/10.1200/JCO.2004.11.061

10. Karapetis CS, Khambata-Ford S, Jonker DJ, O'Callaghan CJ, Tu D, Tebbutt NC, Simes RJ, Chalchal H, Shapiro JD, Robitaille S, Price TJ, Shepherd L, Au HJ, Langer C, Moore MJ, Zalcberg JR. K-ras mutations and benefit from cetuximab in advanced colorectal cancer. N Engl J Med. 2008; 359:1757-65.

DOI:

http://dx.doi.org/10.1056/NEJMoa0804385

11. De Roock W1, Piessevaux H, De Schutter J, Janssens M, De Hertogh G, Personeni N, Biesmans B, Van Laethem JL, Peeters M, Humblet Y, Van Cutsem E, Tejpar S. KRAS wildtype state predicts survival and is associated to early radiological response in metastatic colorectal cancer treated with cetuximab. Ann Oncol. 2008; 19:508-15.

DOI:

http://dx.doi.org/10.1093/annonc/mdm496

12. Kobayashi S, Canepa HM, Bailey AS, Nakayama S, Yamaguchi N, Goldstein MA, Huberman MS, Costa DB. Compound EGFR mutations and response to EGFR tyrosine kinase inhibitors. J Thorac Oncol. 2013; 8:4551.

DOI:

http://dx.doi.org/10.1097/JTO.0b013e318278 $\underline{1 \mathrm{e} 35}$

13. Seth $\mathrm{R}$, Crook $\mathrm{S}$, Ibrahem $\mathrm{S}$, Fadhil W, Jackson D, Ilyas M. Concomitant mutations and splice variants in KRAS and BRAF demonstrate complex perturbation of the Ras/Raf signalling pathway in advanced colorectal cancer. Gut 2009; 58: 1234-1241.

DOI:

http://dx.doi.org/10.1136/gut.2008.159137

14. Pu YS, Huang CY, Kuo YZ, Kang WY, Liu GY, Huang AM, et al. Characterization of membranous and cytoplasmic EGFR expression in human normal renal cortex and renal cell carcinoma. J Biomed Sci 2009; 16: 82.

DOI:

http://dx.doi.org/10.1186/1423-0127-16-82 
15. Bellmunt J, Montagut C, Albiol S, Carles J. Present strategies in the treatment of metastatic renal cell carcinoma: An update on molecular targeting agents. BJU Int 2007; 99: 274-80. [Pubmed]

16. Salomon DS, Brandt R, Ciardiello F, Normanno N. Epidermal growth factor related peptides and their receptors in human malignancies. Crit Rev Oncol Haematol 1995; 19: 183-232. [Pubmed]

17. Kamai T, Arai K, Koga F, Abe H, Nakanishi $\mathrm{K}$, Kambara T. Higher expression of K-ras is associated with parathyroid hormone-related protein-induced hypercalcaemia in renal cell carcinoma. BJU Int 2001; 88: 960-96.

DOI:

http://dx.doi.org/10.1046/j.14644096.2001.01294.x

18. Kozma L, Kiss I, Nagy A, Szakáll S, Ember I. Investigation of c-myc and K-ras amplification in renal clear cell adenocarcinoma. Cancer Lett 1997; 111: 127-131.

DOI:

http://dx.doi.org/10.1016/S03043835(96)04527-2
19. Gattenlöhner S, Etschmann B, Riedmiller H, Müller-Hermelink HK. Lack of KRAS and BRAF mutation in renal cell carcinoma.Eur Urol. 2009 Jun;55(6):1490-1.

DOI:

http://dx.doi.org/10.1016/j.eururo.2009.02.02 $\underline{4}$

20. Szymańska K, Moore LE, Rothman N, Chow WH, Waldman F, Jaeger E, et al. TP53, EGFR, and KRAS mutations in relationt to VHL inactivation and lifestyle risk factors in renalcell carcinoma from Central and Eastern Europe. Cancer Lett. 2010; 293: 92-98.

DOI:

http://dx.doi.org/10.1016/j.canlet.2009.11.024

21. Sakaeda $\mathrm{T}$, Okamura $\mathrm{N}$, Gotoh $\mathrm{A}$, Shirakawa T, Terao S, Morioka M, Tokui K, Tanaka H, Nakamura T, Yagi M, Nishimura Y, Yokoyama M, Okumura K. EGFR mRNA is upregulated, but somatic mutations of the gene are hardly found in renal cell carcinoma in Japanese patients. Pharm Res. 2005; 22:175761.

DOI:

http://dx.doi.org/10.1007/s11095-005-7094-2 